\title{
Expected and Unexpected Products in Half Curcuminoid Synthesis: Crystal Structures of But-3-en-2-ones and 3-Methylcyclohex-2-enones
}

\author{
Marco A. Obregón-Mendoza ${ }^{1}$, Imilla I. Arias-Olguín ${ }^{1}$, William Meza-Morales ${ }^{1}$, Yair Alvarez-Ricardo ${ }^{1}$, \\ María Isabel Chávez ${ }^{1}$, Rubén A. Toscano ${ }^{1} \mathbb{D}$, Julia Cassani ${ }^{2}$ (D) and Raúl G. Enríquez ${ }^{1, *(\mathbb{D})}$ \\ 1 Instituto de Química, Universidad Nacional Autónoma de México, Circuito Exterior, Ciudad Universitaria, \\ Mexico City CDMX 04510, Mexico; obregonmendoza@yahoo.com.mx (M.A.O.-M.); \\ arolima@hotmail.com (I.I.A.-O.); willy_meza_morales@hotmail.com (W.M.-M.); \\ yfar30@hotmail.com (Y.A.-R.); isabel@unam.mx (M.I.C.); toscano@unam.mx (R.A.T.) \\ 2 Departamento de Sistemas Biológicos, Universidad Autónoma Metropolitana, Unidad Xochimilco, \\ Ciudad de México 04960, Mexico; cassani@correo.xoc.uam.mx \\ * Correspondence: enriquezhabib@gmail.com; Tel.: +52-55-56224404
}

Citation: Obregón-Mendoza, M.A.; Arias-Olguín, I.I.; Meza-Morales, W.; Alvarez-Ricardo, Y.; Chávez, M.I.; Toscano, R.A.; Cassani, J.; Enríquez, R.G. Expected and Unexpected Products in Half Curcuminoid Synthesis: Crystal Structures of But-3-en-2-ones and 3-Methylcyclohex-2-enones. Crystals 2021, 11, 404. https://doi.org/ $10.3390 /$ cryst11040404

Academic Editor: Kraig Wheeler

Received: 23 March 2021

Accepted: 7 April 2021

Published: 10 April 2021

Publisher's Note: MDPI stays neutral with regard to jurisdictional claims in published maps and institutional affiliations.

Copyright: (c) 2021 by the authors. Licensee MDPI, Basel, Switzerland. This article is an open access article distributed under the terms and conditions of the Creative Commons Attribution (CC BY) license (https:/ / creativecommons.org/licenses/by/ $4.0 /)$.

\begin{abstract}
The expected (E)-but-3-en-2-ones compounds I and II (half curcuminoids) were obtained by the Claisen-Schmidt reaction between aldehydes 3,4-dimethoxybenzaldehyde or 4-nitrobenzaldehyde with acetone. Concomitantly, 3-methylcyclohex-2-enones compounds III and IV arose from an unexpected reaction of but-3-en-2-ones in the cascade reaction of a Michael-type addition of a second molecule of acetone followed by Robinson annulation under strong basic conditions. Both enones exhibit the (E)-configuration, compound I displays s-trans conformation, whereas compound II exhibits conformational disorder as solid solution of s-cis and s-trans conformations. The related 3-methylcyclohex-2-enones exhibit envelope conformation. Compound III constitutes an example of the rarest case of racemic solid solution (pseudoracemate), where a lack of chiral discrimination with respect to the two enantiomers leads to an enantiomeric disorder of a racemic mixture with different occupancies at the reference site. Due to the lack of strong hydrogen-bond donors in all compounds, the crystal packing is mainly stabilized by weak intermolecular $\mathrm{C}-\mathrm{H} \cdots \mathrm{O}$ interactions between the molecules. The present work provides a new perspective on the search for by-products normally overlooked in Claisen-Schmidt condensations.
\end{abstract}

Keywords: Claisen-Schmidt reaction; Michael reaction; Robinson annulation reaction; half-curcuminoids; (E)-but-3-en-2-ones; 3-methylcyclohex-2-enones

\section{Introduction}

Half curcuminoids [1-3] are typically prepared employing the classical ClaisenSchmidt condensation using strong base catalysis [4]. The resulting product is an $\alpha, \beta-$ unsaturated ketone, usually an E-enone. However, the outcome in chalcone and halfcurcuminoid reactions may vary due to several side reactions. A common reaction observed is the tandem Claisen-Schmidt condensations, leading to mono- and di-benzylidene acetone by-products (Scheme 1, Path I). The prop-2-en-1-one moiety also provides a chemically reactive function for Michael-type additions [4-8], leading to the formation of cyclic structures through a domino reaction $[9,10]$ (Scheme 1, Path II) in the presence of catalysts other than a strong base. Enones and cyclohexenones are the building blocks or synthons $[10,11]$ important in the synthesis of natural products and a wide range of biological activities have been associated with them, such as anti-inflammatory and anticancer effects [12,13]. Furthermore, they are used as food additives and in the synthesis of pheromones [14]. 


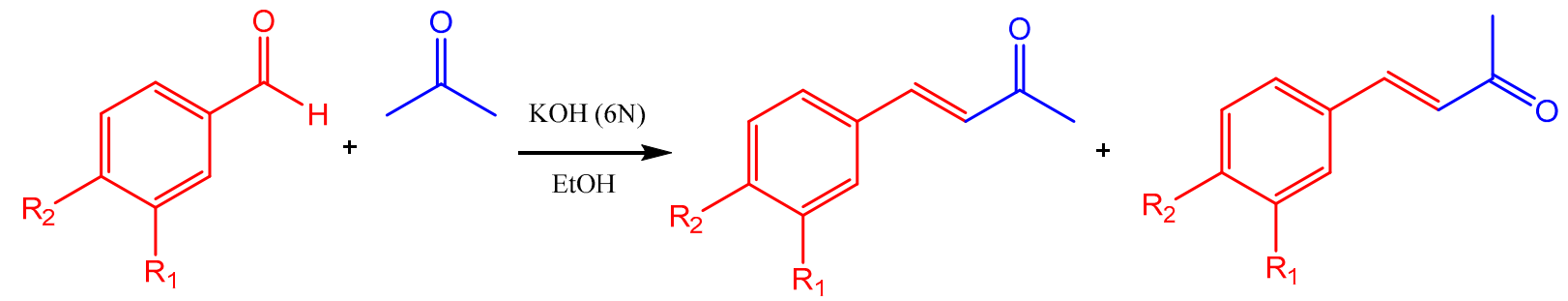

3,4-Dimethoxybenzaldehyde $\mathrm{R}_{1}=\mathrm{OCH}_{3} \mathrm{R}_{2}=\mathrm{OCH}_{3}$ 4-Nitrobenzaldehyde $\mathrm{R}_{1}=\mathrm{H} \mathrm{R}_{2}=\mathrm{NO}_{2}$
(E) s-cis

(E) s-trans

(I) $\mathrm{R}_{1}=\mathrm{OCH}_{3} \mathrm{R}_{2}=\mathrm{OCH}_{3}$

(II) $\mathrm{R}_{1}=\mathrm{H} \mathrm{R}_{2}=\mathrm{NO}_{2}$

\section{Expected}<smiles>[R]c1ccc(/C=C/C(=O)/C=C/c2ccc([R2])c([R])c2)cc1[R]</smiles>

Unobserved

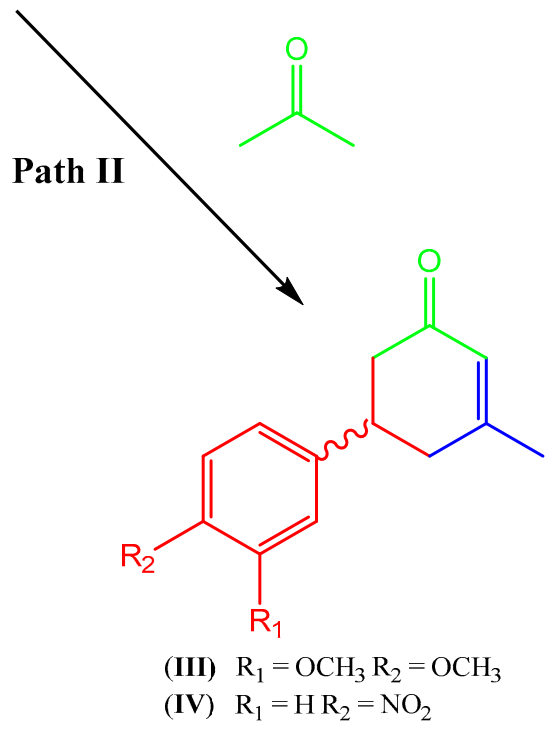

Unexpected

Scheme 1. Synthesis of compounds I-IV.

In our study, the mono Claisen-Schmidt condensation (half-curcuminoids I and II) and the cascade-like Robinson annulation products (compounds III and IV) (Scheme 1, Path II) between two substituted aromatic aldehydes and acetone catalyzed with potassium hydroxide were obtained in a one-pot mode reaction. We report herein the characterization by spectroscopic techniques (NMR ${ }^{1} \mathrm{H},{ }^{13} \mathrm{C}$, and IR), mass spectrometry, and X-ray diffraction of compounds I-IV.

\section{Materials and Methods}

All chemicals were purchased from Sigma-Aldrich. Melting points were determined on an Electrothermal IA9100 digital melting point apparatus (USA) in open capillary tubes and are uncorrected. IR absorption spectra were recorded in the $4000-400 \mathrm{~cm}^{-1}$ range as $\mathrm{KBr}$ pellets on a Perkin Elmer 283-B spectrophotometer (USA). ${ }^{1} \mathrm{H}$ and ${ }^{13} \mathrm{C} \mathrm{NMR}$ spectra were recorded in $\mathrm{CDCl}_{3}$ with a Bruker $500 \mathrm{MHz}$ spectrometer (Bruker Mexicana S.A. de C. V., Mexico, CDMX) using Tetramethylsilane as an internal reference. NMR spectra were processed with MNova 12.0.0 software [15]. The Mass Spectra data were recorded on an MStation JMS-700 (JEOL Mexico S.A of C.V., México, CDMX) or Jeol SX 102A instrument, using electron ionization impact (See supplementary materials). Single-crystal X-ray diffraction was carried out using a Bruker diffractometer (Bruker Mexicana S.A. de C. V., Mexico, CDMX), model Smart Apex, or D8 Venture, equipped with Mo $K \alpha, \lambda=0.71073$ $\AA$. The data were collected and reduced using APEX and SAINT-Plus programs. The 
structures were solved by direct methods and non-hydrogen atoms were refined by a fullmatrix least-squares procedure on $F^{2}$ with anisotropic temperature factors using SHELX programs [16]. The positions of all $\mathrm{H}$ atoms were calculated geometrically, and a riding model was used in the refinement, with $\mathrm{C}-\mathrm{H}$ distances in the range of $0.93-0.97 \AA$ and $U_{\text {iso }}(\mathrm{H})=1.2 U_{\text {eq }}(\mathrm{C})$. As disorder was found for compounds II and III, the site occupancy factors (sof) of disordered atoms were refined, and disordered moieties were refined using distance restraints (SADI, SAME) and ADP restraints (DELU, SIMU, and ISOR). Mercury 4.2 software was used to prepare the graphs for publication [17]. The rather high $\mathrm{R}$ merge values and the lower than 10 ratios of observed reflections to parameters for the four structures can be attributed to a combination of crystals poorly scattering to the Mo radiation, disorder in the structures, and the almost planar conformation of compounds.

\section{Synthesis and Crystallization}

In a $250 \mathrm{~mL}$ round bottom flask, $250 \mathrm{mg}$ of 3,4-dimethoxybenzaldehyde, $1.5 \mathrm{mmol}$; or 4-nitrobenzaldehyde, $1.65 \mathrm{mmol}$, were dissolved in $50 \mathrm{~mL}$ of acetone; then, $3 \mathrm{~mL}$ of a $6 \mathrm{~N}$ potassium hydroxide $(\mathrm{KOH})$ solution in ethanol $(\mathrm{EtOH})$ was added dropwise (Scheme 1). The reaction mixture was stirred at room temperature and monitored by Thin Layer Chromatography (TLC; silica gel $60 \AA \mathrm{F}_{254}$ plates, Merck) eluting with hexane-ethyl acetate (7:3). After completion of the reaction (ca. $24 \mathrm{~h}$ ), the acetone was evaporated in vacuo and the reaction mixture was poured over ice and acidulated with diluted hydrochloric acid $(\mathrm{HCl})$ to $\mathrm{pH}=5$. The reaction mixture was extracted three times with EtOAc $(3 \times 15 \mathrm{~mL})$. The combined organic extracts were dried over anhydrous $\mathrm{Na}_{2} \mathrm{SO}_{4}$, then filtered and the solvent was removed in vacuo. Finally, the crude reaction mixture was purified by column chromatography using Sigma silica gel $60 \AA$ mesh 70-230, eluting with a gradient of hexane-ethyl acetate (7:3). Adequate crystals for X-ray studies of the four compounds were obtained by slow evaporation from ethyl acetate at room temperature.

(E)-4-(3,4-dimethoxyphenyl)but-3-en-2-one (I), white solid (217 mg, 70\%), m.p. $84{ }^{\circ} \mathrm{C}$. IR 3012-2917.01, 1664.01, 1617.06, 1592.30, 1509.52, 1420.58, 1222.80, 1159.99,1136.69, 1016.92, $975.28 \mathrm{~cm}^{-1} .{ }^{1} \mathrm{H}$ NMR: $\delta_{\mathrm{H}}\left(500 \mathrm{MHz}, \mathrm{CDCl}_{3}\right) 7.46(\mathrm{~d}, J=16.2 \mathrm{~Hz}, 1 \mathrm{H}), 7.13(\mathrm{ddd}, J=8.3,2.1$, $0.5 \mathrm{~Hz}, 1 \mathrm{H}), 7.08(\mathrm{~d}, J=2.1 \mathrm{~Hz}, 1 \mathrm{H}), 6.88(\mathrm{~d}, J=8.3 \mathrm{~Hz}, 1 \mathrm{H}), 6.61(\mathrm{~d}, J=16.2 \mathrm{~Hz}, 1 \mathrm{H}), 3.92$ (s, 6H), $2.37(\mathrm{~s}, 3 \mathrm{H}) .{ }^{13} \mathrm{C}$ NMR: $\delta_{\mathrm{C}}\left(125 \mathrm{MHz}, \mathrm{CDCl}_{3}\right)$ 198.28, 151.40, 149.33, 143.73, 127.37, $125.28,123.00,111.14,109.70,56.00,55.92,27.35$. (MS): $\mathrm{M} / \mathrm{z}=206$.

(E)-4-(4-nitrophenyl)but-3-en-2-one (II), yellow pale solid $(126 \mathrm{mg}, 40 \%), \mathrm{m} . \mathrm{p} 106{ }^{\circ} \mathrm{C}$. IR 3456.35, 3112.33, 2926.22, 1665.44, 1594.95, 1517.16, 1345.61, 1259.71, 1108.52, $977.24 \mathrm{~cm}^{-1}$. ${ }^{1} \mathrm{H}$ NMR: $\delta_{\mathrm{H}}\left(500 \mathrm{MHz}, \mathrm{CDCl}_{3}\right) 8.31-8.21(\mathrm{~m}, 2 \mathrm{H}), 7.75-7.66(\mathrm{~m}, 2 \mathrm{H}), 7.54(\mathrm{~d}, J=16.3 \mathrm{~Hz}$, $1 \mathrm{H}), 6.83(\mathrm{~d}, J=16.3 \mathrm{~Hz}, 1 \mathrm{H}), 2.43(\mathrm{~s}, 3 \mathrm{H}) .{ }^{13} \mathrm{C} \mathrm{NMR:} \delta_{\mathrm{C}}\left(125 \mathrm{MHz}, \mathrm{CDCl}_{3}\right)$ 197.49, 148.62, $140.69,140.05,130.40,128.81,124.20,28.04$. (MS): M/z 191.

5-(3,4-dimethoxyphenyl)-3-methylcyclohex-2-enone (III), yellow solid (92 mg, 25\%), m.p. $89^{\circ}$ C. IR 2916.80, 2836.63, 1657.54, 1590.17, 1512.54, 1590.17, 1512.61, 1245.13, 1139.33, $1021.15 \mathrm{~cm}^{-1} .{ }^{1} \mathrm{H}$ NMR: $\delta_{\mathrm{H}}\left(500 \mathrm{MHz}, \mathrm{CDCl}_{3}\right) 6.86-6.83(\mathrm{~m}, 1 \mathrm{H}), 6.79(\mathrm{ddd}, J=8.2,2.1$, $0.6 \mathrm{~Hz}, 1 \mathrm{H}), 6.76-6.75(\mathrm{~m}, 1 \mathrm{H}), 5.97(\mathrm{~m}, 1 \mathrm{H}), 3.88(\mathrm{~s}, 3 \mathrm{H}), 3.87(\mathrm{~s}, 3 \mathrm{H}), 3.32-3.23(\mathrm{~m}, 1 \mathrm{H}), 2.64$ $(\mathrm{ddt}, J=16.2,3.7,0.7 \mathrm{~Hz}, 1 \mathrm{H}), 2.56-2.49(\mathrm{~m}, 3 \mathrm{H}), 2.01(\mathrm{dt}, J=1.4,0.8 \mathrm{~Hz}, 3 \mathrm{H}) .{ }^{13} \mathrm{C}$ NMR: $\delta_{\mathrm{C}}$ $\left(125 \mathrm{MHz}, \mathrm{CDCl}_{3}\right)$ 199.09, 161.57, 149.08, 147.97, 136.05, 126.53, 118.45, 111.43, 110.18, 55.97, 55.92, 44.19, 40.40, 39.23, 24.34. (MS): M/z = 246.

3-methyl-5-(4-nitrophenyl)cyclohex-2-enone (IV), pale yellow solid (75 mg, 20\%), m.p. $120{ }^{\circ} \mathrm{C}$. IR 3425.99, 2939.55, 1660.39, 1600.31, 1518.1, 1344.17, $1107.30 \mathrm{~cm}^{-1}$. ${ }^{1} \mathrm{H}$ NMR: $\delta_{\mathrm{H}}\left(500 \mathrm{MHz} \mathrm{CDCl}_{3}\right) \delta 8.28-8.17(\mathrm{~m}, 2 \mathrm{H}), 7.50-7.39(\mathrm{~m}, 2 \mathrm{H}), 6.08-5.96(\mathrm{~m}, 1 \mathrm{H}), 3.64-3.39$ $(\mathrm{m}, 1 \mathrm{H}), 2.73-2.63(\mathrm{~m}, 1 \mathrm{H}), 2.63-2.52(\mathrm{~m}, 3 \mathrm{H}), 2.04(\mathrm{dd}, J=1.4,0.8 \mathrm{~Hz}, 3 \mathrm{H}) .{ }^{13} \mathrm{C}$ NMR: $\delta_{\mathrm{C}}$ $\left(125 \mathrm{MHz}, \mathrm{CDCl}_{3}\right)$ 197.61, 160.81, 150.52, 147.00, 127.70, 126.74, 124.09, 43.20, 40.55, 38.25, 24.32. (MS): $\mathrm{M} / \mathrm{z}=231$. 


\section{Results}

The geometry of the molecules of compounds I-IV are shown in Figures 1-4, respectively, and they are in agreement with analogous structures reported in the literature. Refinement parameters are show in Table 1.

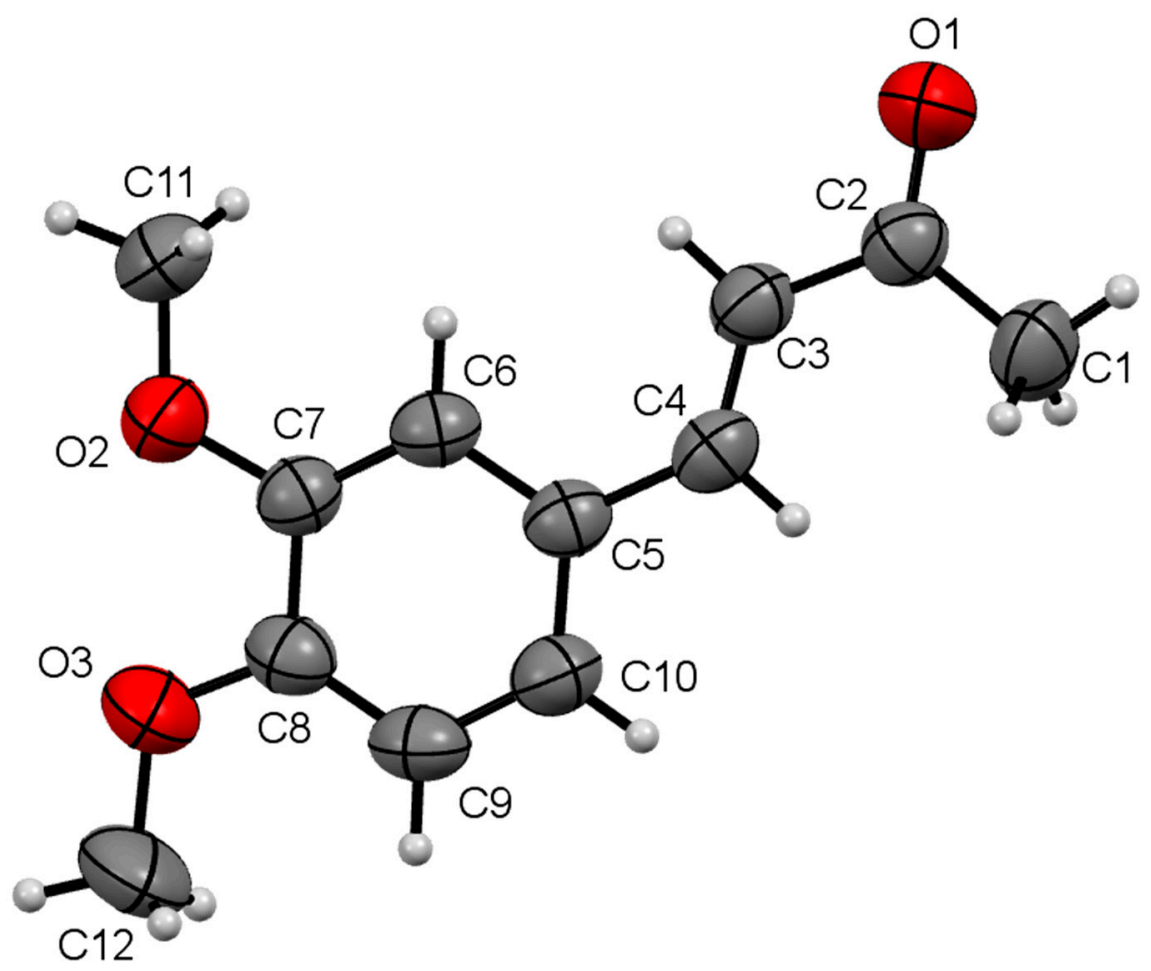

Figure 1. The ORTEP drawing of the molecule of compound I with displacement ellipsoids drawn at the $50 \%$ probability level.

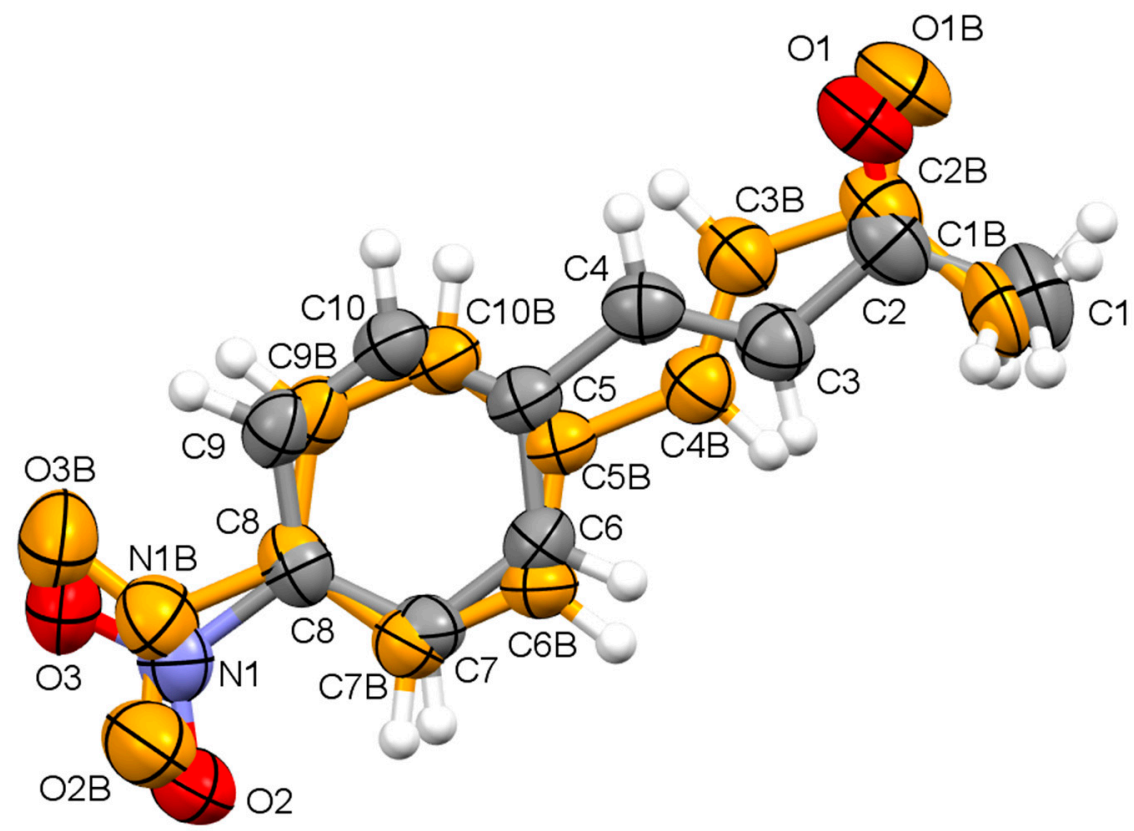

Figure 2. The ORTEP drawing of disordered compound II showing displacement ellipsoids drawn at the $50 \%$ probability level (minor conformer in orange). 


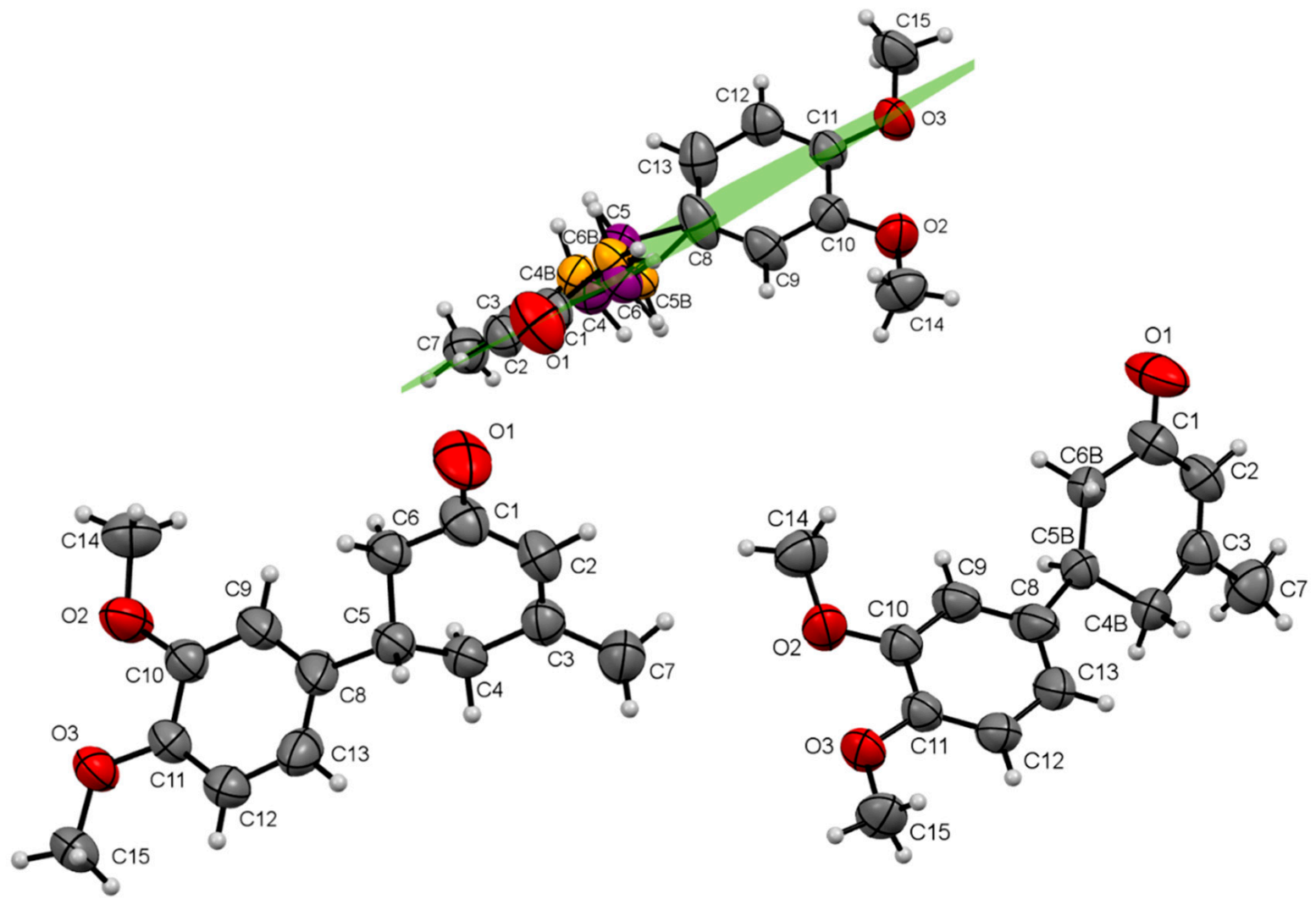

Figure 3. The ORTEP drawing of the disorder in compound III showing displacement ellipsoids drawn at the $50 \%$ probability level.

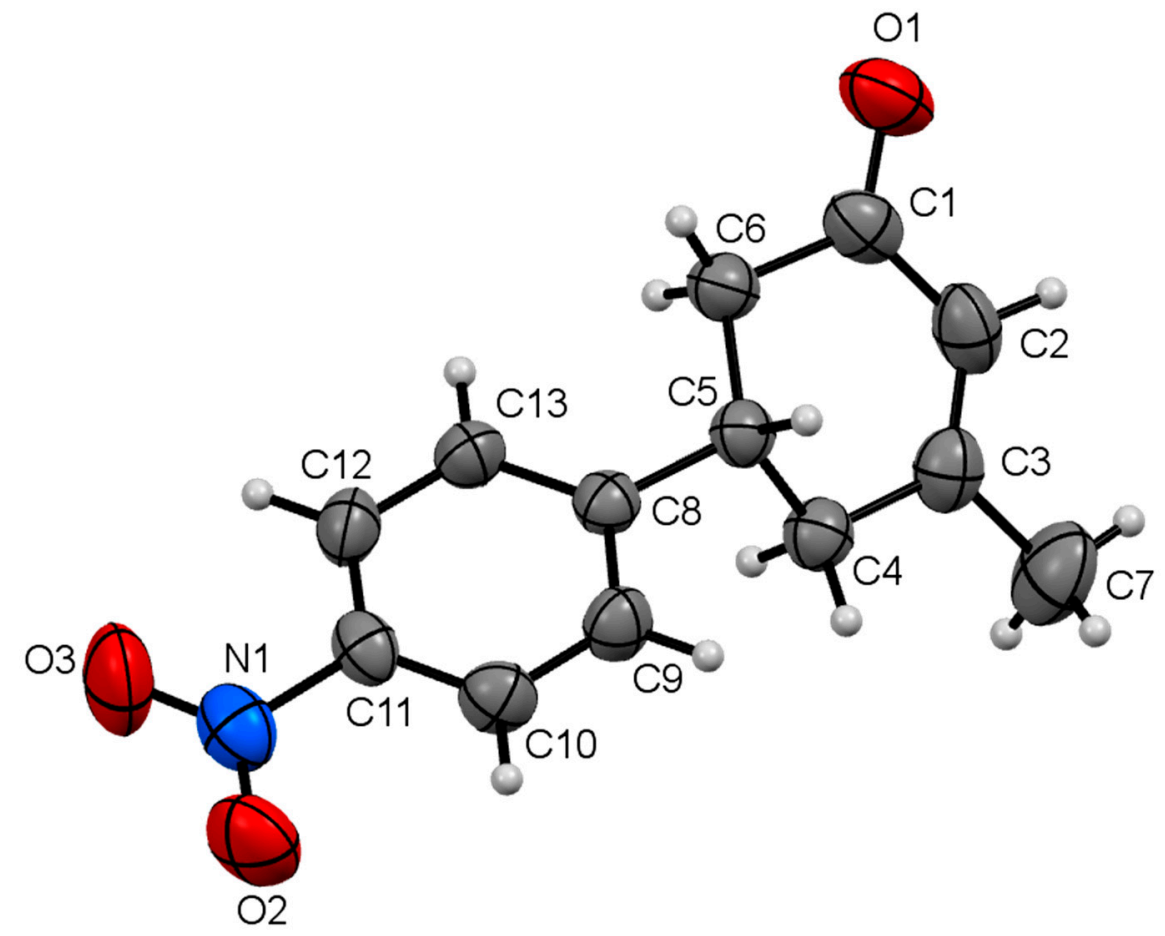

Figure 4. The ORTEP drawing of compound IV showing displacement ellipsoids drawn at the $50 \%$ probability level. 
Table 1. Experimental details.

\begin{tabular}{|c|c|c|c|c|}
\hline Compound & $\mathbf{I}$ & II & III & IV \\
\hline Crystal system & $\begin{array}{l}\text { Monoclinic } \\
a=9.6000(7)\end{array}$ & $\begin{array}{l}\text { Monoclinic } \\
\mathrm{a}=7.4561(4)\end{array}$ & $\begin{array}{c}\text { Monoclinic } \\
\mathrm{a}=13.0205(10)\end{array}$ & $\begin{array}{c}\text { Monoclinic } \\
a=4.9301(18)\end{array}$ \\
\hline \multirow{3}{*}{ Unit cell parameters $\left[\AA^{\circ},{ }^{\circ}\right]$} & $b=5.3426(4)$ & $\mathrm{b}=7.2591(4)$ & $\mathrm{b}=8.0494(6)$ & $\mathrm{b}=23.652(9)$ \\
\hline & $c=22.353(2)$ & $c=17.7744(10)$ & $c=14.1040(11)$ & $c=10.014(4)$ \\
\hline & $\beta=97.307(2)$ & $\beta=94.505(2)$ & $\beta=114.852(2)$ & $\beta=97.692(12)$ \\
\hline Volume $\left[\AA^{3}\right]$ & $1137.17(14)$ & $959.06(9)$ & 1341.32(18) & $1157.2(8)$ \\
\hline $\mathrm{Z} /$ Calculated density $\left[\mathrm{mg} / \mathrm{m}^{3}\right]$ & $4 / 1.205$ & $4 / 1.324$ & $4 / 1.220$ & $4 / 1.327$ \\
\hline$Z^{\prime}$ & 1 & 1 & 1 & 1 \\
\hline Absorption coefficient $\left[\mathrm{mm}^{-1}\right]$ & 0.086 & 0.099 & 0.084 & 0.095 \\
\hline \multirow[t]{2}{*}{ Space group, $F(000)$} & $P 2_{1} / \mathrm{n}, 440$ & $P 2_{1} / \mathrm{n}, 400$ & $P 2_{1} / c, 528$ & $P 2_{1} / \mathrm{c}, 488$ \\
\hline & $-11 \leq h \leq 11$ & $-8 \leq h \leq 9$ & $-15 \leq h \leq 15$ & $-6 \leq h \leq 6$ \\
\hline \multirow{2}{*}{ Index ranges } & $-6 \leq k \leq 6$ & $-9 \leq k \leq 9$ & $-8 \leq k \leq 9$ & $-30 \leq k \leq 30$ \\
\hline & $-25 \leq l \leq 26$ & $-23 \leq l \leq 21$ & $-11 \leq l \leq 16$ & $-13 \leq l \leq 13$ \\
\hline Reflections collected & 6066 & 16,684 & 5906 & 31,441 \\
\hline Independent reflections & $\begin{array}{c}2071 \\
{[R \text { (int) }=0.0722]}\end{array}$ & $\begin{array}{c}2446 \\
R \text { (int) }=0.0940]\end{array}$ & $\begin{array}{c}2442 \\
{[R \text { (int) }=0.1320]}\end{array}$ & $\begin{array}{c}2663 \\
{[R(\text { int })=0.1187]}\end{array}$ \\
\hline $\begin{array}{l}\text { Observed reflections } \\
(I>2 \sigma(I))\end{array}$ & 1100 & 935 & 1383 & 1290 \\
\hline Completeness to $\theta=25.10$ & $99.6 \%$ & $99.8 \%$ & $99.6 \%$ & $99.7 \%$ \\
\hline Data/restraints/parameters & $2071 / 0 / 139$ & $2194 / 247 / 441$ & $2442 / 72 / 195$ & $2663 / 0 / 155$ \\
\hline Final $R$ indices & $\mathrm{R} 1=0.0482$ & $\mathrm{R} 1=0.0532$ & $\mathrm{R} 1=0.0631$ & $\mathrm{R} 1=0.0516$ \\
\hline$(I \geq 2 \sigma(I))$ & $w R 2=0.1026$ & $\mathrm{wR} 2=0.1047$ & $w R 2=0.1370$ & $\mathrm{wR} 2=0.0907$ \\
\hline$R$ indices (all data) & $\mathrm{R} 1=0.1005$ & $\mathrm{R} 1=0.1416$ & $\mathrm{R} 1=0.1204$ & $\mathrm{R} 1=0.1469$ \\
\hline & $w R 2=0.1304$ & $\mathrm{wR} 2=0.1670$ & $w R 2=0.1712$ & $\mathrm{wR} 2=0.1203$ \\
\hline Goodness-of-fit on $F^{2}$ & 0.940 & 0.995 & 1.025 & 1.005 \\
\hline Largest diff. peak/hole $\left[\mathrm{e} \cdot \AA^{-3}\right]$ & $0.197 /-0.172$ & $0.114 /-0.131$ & $0.198 /-0.268$ & $0.174 /-0.139$ \\
\hline CCDC deposit number & 2075964 & 2075965 & 2075966 & 2075970 \\
\hline
\end{tabular}

\section{Discussion}

The molecular structure of Compound I is shown in Figure 1. This structure is essentially planar and has $(E)$ configuration for the $C=C$ double bond and an s-trans conformation between the double $\mathrm{C}=\mathrm{C}$ bond and the carbonyl group. A cluster analysis applied to the conformational analysis of enones and enimines in the crystalline solid state, using structural information mined from the Cambridge Structural Database [18], revealed that trans s-trans enones are less commonly observed than trans s-cis enones; however, this trend is reversed for the subgroup of 4- $R$-but-3-en-2-ones for which the trans s-trans $\left(-4.02 \mathrm{Kcal} \cdot \mathrm{mol}^{-1}\right)$ is theoretically predicted [19] as the most stable form with respect to trans s-cis $\left(-1.83 \mathrm{Kcal} \mathrm{mol}^{-1}\right)$ and the relative energy of trans s-cis-geometry with respect to trans s-trans is ca. $2 \mathrm{Kcal} \mathrm{mol}^{-1}$ [19].

At an early stage of refinement of compound II, it was apparent that the molecule was rather disordered over two sets of overlapping atomic sites (Figure 2) having unequal occupancies. On this basis, the occupancies of the two disordered components refined to $0.703(4)$ and $0.297(4)$, the major disordered component corresponds to the trans s-cis conformation, and the minor component to the trans s-trans conformation of the but3-en-2-one moiety, rendering a solid solution of conformers. A rather similar disorder was reported by Zhang et al. [20] for (E)-2-methoxy-4-(3-oxobut-1-enyl)phenyl acetate approaching a near equimolecular ratio of conformers favoring slightly the trans s-trans conformation. The s-trans and s-cis conformations in solid and liquid state are different, although in the solid state, molecules can exist in the crystal in either s-trans or s-cis conformations depending on the temperature at which crystals are grown [21]. However, in liquid state the s-trans conformer is the dominant one at room temperature [22], with a conformational barrier going from the s-trans to the s-cis conformer of $8.9 \mathrm{Kcal} \mathrm{mol}^{-1}$ in acrolein [23].

Compound III (Scheme 1) contains a stereogenic center at position five of the cyclohexenone ring, and the systematic absences in the diffraction data were uniquely consistent for the space group $P 2_{1} / c$, confirming that this compound crystallizes as a racemic mixture of $(5 R)$ and $(5 S)$ enantiomers. However, with $Z^{\prime}=1$, the compound exhibits enantiomeric 
disorder such that both enantiomers $R$ and $S$ are superimposed, each adopting opposite conformations. The static disorder in compound III can be represented by atoms C4, C5, and $\mathrm{C} 6$ having two almost mirror-related positions, while the other atoms have single positions; the refined occupancy of the split atoms leads to 0.537(10) for $S$ and 0.463(10) for the crystal selected for data collection. Non-centrosymmetric space groups $(P \mathrm{n}$ and $P 2_{1}$ ) were then tested, without improvement in the refinements: in $P \mathrm{n}$, the results were very similar both for the disorder distribution and for the residual factors, but with high parameter correlation and non-definite atomic displacement tensors. Consequently, the structure was considered as centrosymmetric. In the major conformational component, the ring puckering parameters [24] calculated for the atom sequence $\mathrm{C} 1-\mathrm{C} 2-\mathrm{C} 3-\mathrm{C} 4-\mathrm{C} 5-\mathrm{C} 6$ are $Q=0.472(11) \AA, \theta=46.3(10)^{\circ}$, and $\phi=238.8(15)^{\circ}$, which indicate an approximate envelope conformation with $\mathrm{C} 5$ as a flap. The corresponding ring puckering parameters for the minor component, calculated for the atom sequence $\mathrm{C} 1-\mathrm{C} 2-\mathrm{C} 3-\mathrm{C} 24 \mathrm{~B}-\mathrm{C} 25 \mathrm{~B}-\mathrm{C} 26 \mathrm{~B}$ are $\mathrm{Q}=0.512(12) \AA, \theta=134.7(11)^{\circ}$, and $\phi=62.2(17)^{\circ}$, confirming the change in enantiomorph At $\mathrm{C} 5$ the dimethoxyphenyl substituent occupy the equatorial position making a dihedral angle of $54.5^{\circ}$ with the mean plane of the methylcyclohexenone. The shape of the molecules in the crystal structure of the enantiomers disorder almost has a symmetry plane (Figure 3).

These structural features show that both enantiomers have a high degree of isosterism, minimizing the relative importance of chirality in the geometry of enantiomers while opening the possibility of exchange among the crystals, thus leading to formation of solid solutions [25-27].

In compound IV (Scheme 1 and Figure 4), the six-membered ring puckering parameters [24] calculated for the atom sequence C1-C2-C3-C4-C5-C6 are $\mathrm{Q}=0.461(2) \AA$, $\theta=52.7(2)^{\circ}$, and $\phi=253.6(3)^{\circ}$, which indicate an approximate envelope conformation with $\mathrm{C} 5$ as a flap with the phenyl in equatorial position forming a dihedral angle of $44.10(8)^{\circ}$.

\section{Crystal Packing}

Due to the lack of strong hydrogen bond donors in all compounds, the crystal packing is mainly stabilized by weak intermolecular $\mathrm{C}-\mathrm{H} \cdots \mathrm{O}$ interactions and eventually $\mathrm{C}-\mathrm{H} \cdots \pi$ interactions (Table 2). Besides planar nature of compounds and the presence of phenyl rings, stacking was observed only in one case (compound II) $\pi \cdots \pi$.

Table 2. Geometry of the hydrogen bonding interactions $\left(\AA^{\circ},{ }^{\circ}\right)$ for compounds I-IV.

\begin{tabular}{|c|c|c|c|c|c|c|}
\hline Compound & D-H $\cdots A$ & D-H & $\mathbf{H} \cdots \mathbf{A}$ & $\mathbf{D} \cdots \mathbf{A}$ & D-H $\cdots A$ & Symmetry Code \\
\hline \multirow{6}{*}{ I } & $\mathrm{C} 1-\mathrm{H} 1 \mathrm{~A} \cdots \mathrm{O} 1$ & 0.960 & 2.61 & $3.529(3)$ & 160.3 & $x,-1+y, z$ \\
\hline & $\mathrm{C} 3-\mathrm{H} 3 \cdots \mathrm{O} 1$ & 0.930 & 2.60 & $3.503(2)$ & 162.4 & $1-\mathrm{x}, 1-\mathrm{y}, 1-\mathrm{z}$ \\
\hline & $\mathrm{C} 6-\mathrm{H} 6 \cdots \mathrm{O} 1$ & 0.930 & 2.62 & $3.545(3)$ & 173.8 & $1-x, 1-y, 1-z$ \\
\hline & C11-H11B ‥Cg1 & 0.960 & 2.84 & $3.724(2)$ & 154.0 & $\mathrm{x}, 1+\mathrm{y}, \mathrm{z}$ \\
\hline & $\mathrm{C} 9-\mathrm{H} 9 \cdots \mathrm{Cg} 1$ & 0.930 & 3.05 & $3.733(2)$ & 131.9 & $1 / 2-x,-1 / 2+y, 1 / 2-z$ \\
\hline & C12-H12C $\cdots C 3,4$ & 0.960 & 2.84 & $3.751(2)$ & 143.3 & $1 / 2-x,-1 / 2+y, 1 / 2-z$ \\
\hline \multirow{5}{*}{ II } & $\mathrm{C} 7-\mathrm{H} 7 \cdots \mathrm{O} 2$ & 0.930 & 2.57 & $3.327(9)$ & 138.9 & $-\mathrm{x},-\mathrm{y}, 1-\mathrm{z}$ \\
\hline & $\mathrm{C} 9-\mathrm{H} 9 \ldots \mathrm{O} 3$ & 0.930 & 2.57 & $3.301(9)$ & 135.8 & $-x+1 / 2, y+1 / 2,-z+3 / 2$ \\
\hline & $\mathrm{C} 4-\mathrm{H} 4 \cdots \mathrm{O} 1$ & 0.930 & 2.72 & $3.559(7)$ & 150.0 & $1-x, 2-y, 1-z$ \\
\hline & 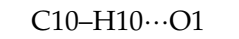 & 0.930 & 2.72 & $3.539(6)$ & 147.9 & $1-x, 2-y, 1-z$ \\
\hline & C6-H6A $\cdots \mathrm{O} 1$ & 0.970 & 2.59 & $3.539(10)$ & 164.5 & $-\mathrm{x},-\mathrm{y}+1,-\mathrm{z}+1$ \\
\hline \multirow{5}{*}{ III } & C9-H9...O1 & 0.930 & 2.65 & $3.467(3)$ & 146.3 & $1-x, y+1 / 2,-z+1 / 2$ \\
\hline & C15-H15A $\cdots$ O2 & 0.960 & 2.62 & $3.519(3)$ & 155.5 & $-\mathrm{x}, 1-\mathrm{y}, 1-\mathrm{z}$ \\
\hline & 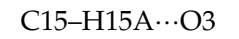 & 0.960 & 2.80 & $3.446(3)$ & 126.0 & $-\mathrm{x}, 1-\mathrm{y}, 1-\mathrm{z}$ \\
\hline & C14-H14A…O1 & 0.960 & 2.86 & $3.806(3)$ & 170.0 & $1-\mathrm{x}, 1-\mathrm{y}, 1-\mathrm{z}$ \\
\hline & $\mathrm{C} 4 \mathrm{~B}-\mathrm{H} 4 \mathrm{C} \cdots \mathrm{O} 3$ & 0.970 & 2.66 & $3.585(10)$ & 159.0 & $x, 1 / 2-y,-1 / 2+z$ \\
\hline \multirow{8}{*}{ IV } & C6-H6A …O1 & 0.970 & 2.64 & $3.581(3)$ & 162.7 & $-1+x, y, z$ \\
\hline & C6-H6B $\cdots \mathrm{O} 1$ & 0.970 & 2.88 & $3.829(3)$ & 166.0 & $-x, 1-y, 1-z$ \\
\hline & $\mathrm{C} 7-\mathrm{H} 7 \mathrm{~B} \cdots \mathrm{O} 3$ & 0.960 & 2.68 & $3.467(3)$ & 139.0 & $-1+x, y, 1+z$ \\
\hline & $\mathrm{C} 12-\mathrm{H} 12 \cdots \mathrm{O} 1$ & 0.930 & 2.66 & $3.343(3)$ & 131.0 & $1-x, 1-y, 1-z$ \\
\hline & $\mathrm{C} 4-\mathrm{H} 4 \mathrm{~A} \cdots \mathrm{O} 2$ & 0.970 & 2.72 & $3.327(3)$ & 121.0 & $-1+x, 1 / 2-y, 1 / 2+z$ \\
\hline & $\mathrm{C} 9-\mathrm{H} 9 \cdots \mathrm{O} 3$ & 0.930 & 2.73 & $3.630(3)$ & 162.0 & $-1+x, 1 / 2-y, 1 / 2+z$ \\
\hline & 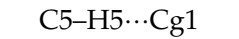 & 0.980 & 2.98 & $3.824(3)$ & 145.0 & $-1+x, y, z$ \\
\hline & $\mathrm{C} 4-\mathrm{H} 4 \mathrm{~B} \cdots \mathrm{C} 2,3$ & 0.970 & 2.84 & $3.788(3)$ & 165.0 & $-1+x, y, z$ \\
\hline
\end{tabular}


The crystal packing of compound I is shown in Figure 5. Double-strand twisted ribbons are formed by $\mathrm{C}-\mathrm{H} \cdots \mathrm{O}$ interactions (Table 2), which are held together by $\mathrm{C}-\mathrm{H} \cdots \pi$ (average $\mathrm{C}-\mathrm{H} \cdots \mathrm{Cg}$ separation $=3.729(2) \AA$, average $\mathrm{C}-\mathrm{H} \cdots \mathrm{C}=\mathrm{C}$ separation $=3.751(2) \AA$ ).

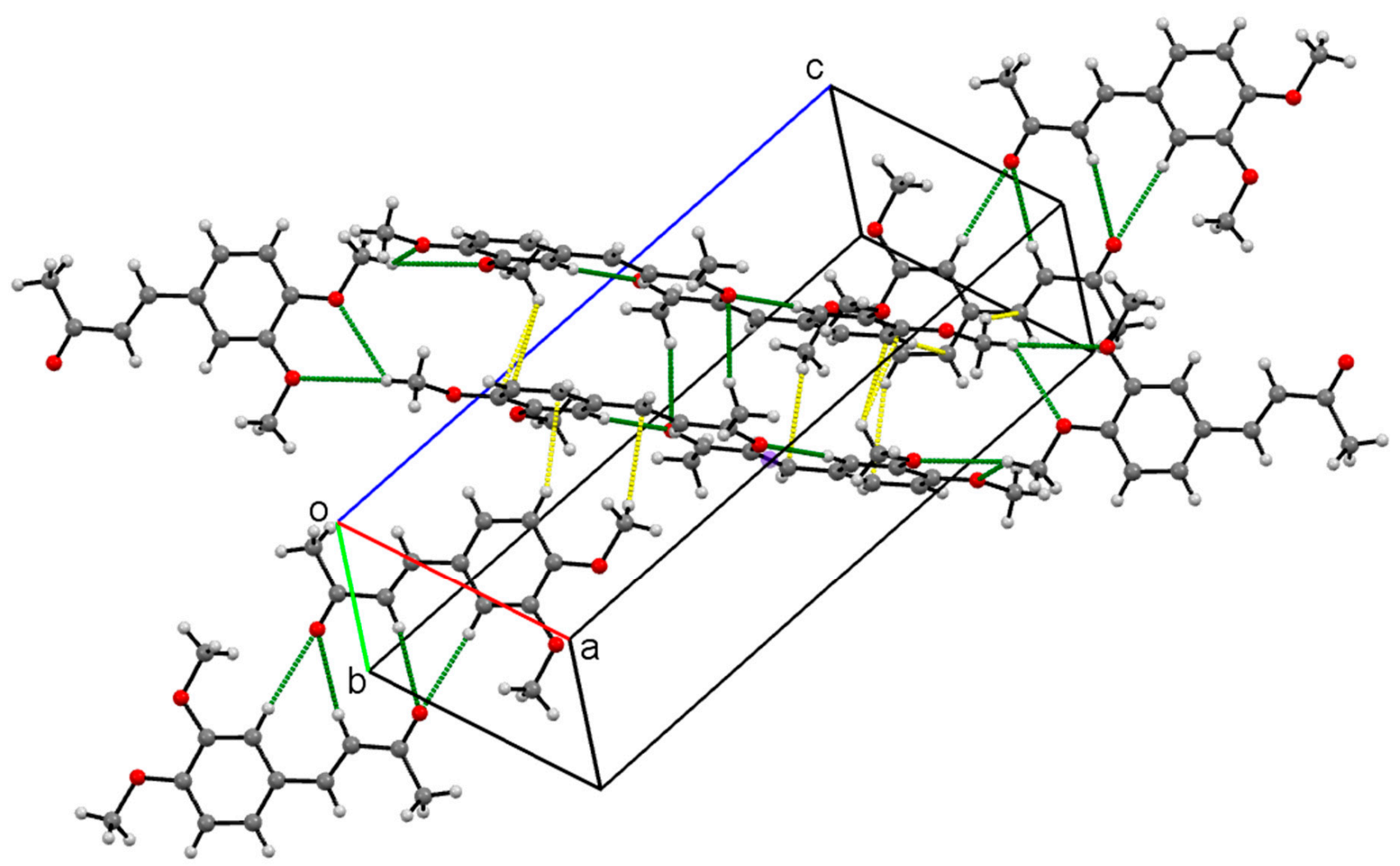

Figure 5. Packing of the crystal of compound I short contacts $\mathrm{C}-\mathrm{H} \cdots \mathrm{O}$ (dashed green line) and $\mathrm{C}-\mathrm{H} \cdots \pi$ (dashed yellow line).

Figure 6 clearly shows the effect of isosterism of both conformations upon the crystal packing of compound II; essentially the same kind of interactions are observed among molecules. Columns of $\pi \cdots \pi$ stacking molecules along the $a$-axis (average $\mathrm{Cg} \cdots \mathrm{Cg}$ separation $=3.843(4) \AA$, average $\mathrm{Cg} \cdots \mathrm{C}=\mathrm{C}$ separation $=3.468(11) \AA$ ) are interconnected by $\mathrm{C}-\mathrm{H} \cdots \mathrm{O}$ interactions involving aromatic and olefinic hydrogens and the oxygen atoms of ketone and nitro moieties (Table 2).

Packing for compound III: The smallest intermolecular contact for the non-disordered common part of enantiomers is between the methoxy substituents leading to formation of centrosymmetric dimers. This implies that $R$ and $S$ enantiomers of compound III should be involved, but by virtue of the observed isosterism, the interchanging of enantiomers is

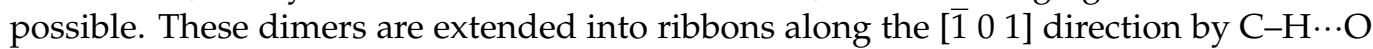
interactions (C6-H6A...O 1 and $\mathrm{C} 9-\mathrm{H} 9 \cdots \mathrm{O} 1)$ and the ribbons weakly interconnected by C14-H14A …O 1 interactions (Figure 7, Table 2).

Finally, in compound IV, centrosymmetric dimers are built from interaction of the oxygen of the carbonyl group and the $\alpha$-methylene of cyclohexenone (Figure 8, red molecules) and with an aromatic hydrogen (Figure 8, blue molecules) interconnected by the nitro group into a tridimensional network, reinforced by $\mathrm{C}-\mathrm{H} \cdots \pi$ and additional $\mathrm{C}-\mathrm{H} \cdots \mathrm{O} 1$ interactions (Table 2). 


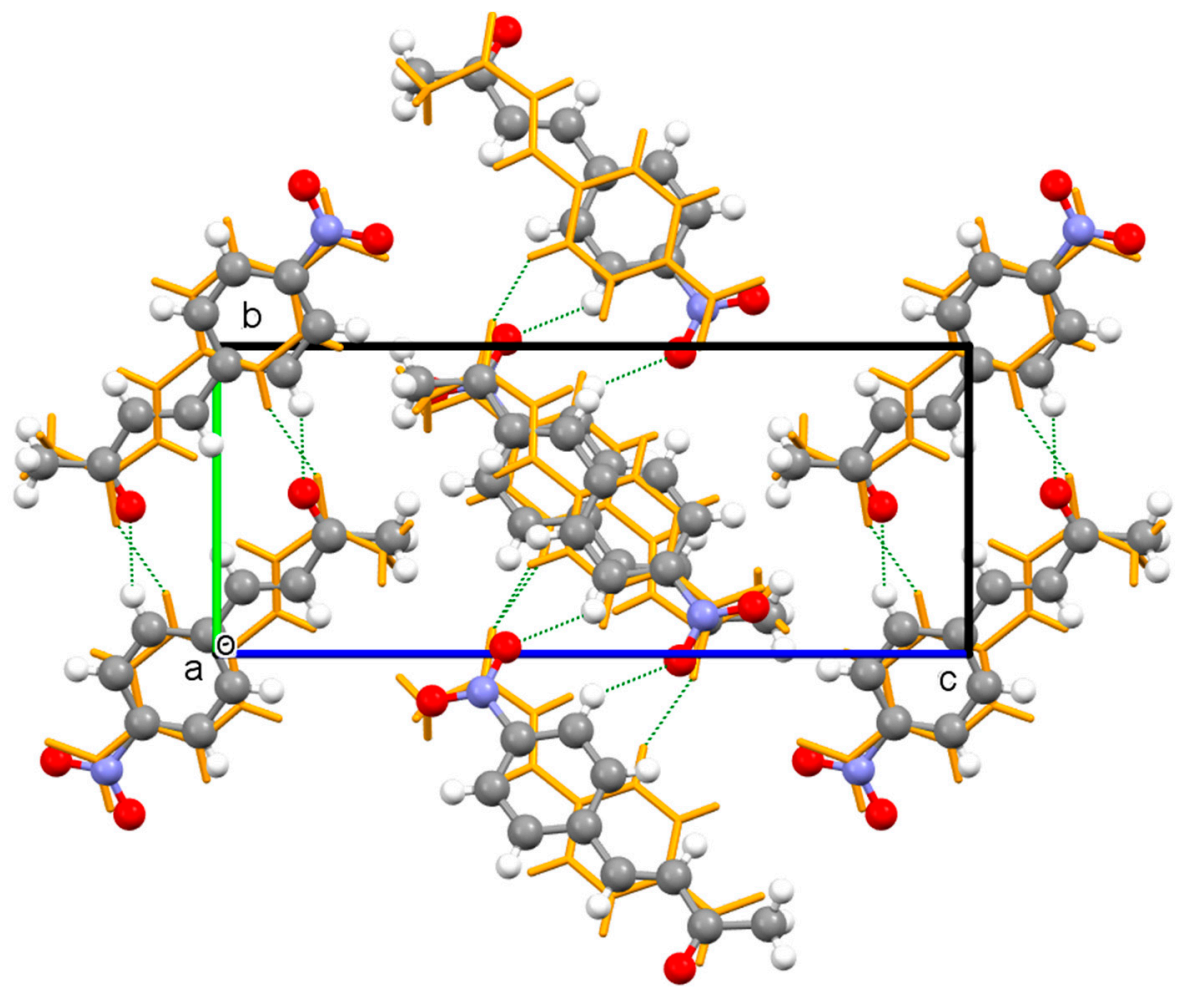

Figure 6. Crystal packing of compound II, minor component in orange and $\mathrm{C}-\mathrm{H} \cdots \mathrm{O}$ contacts as dashed green lines.

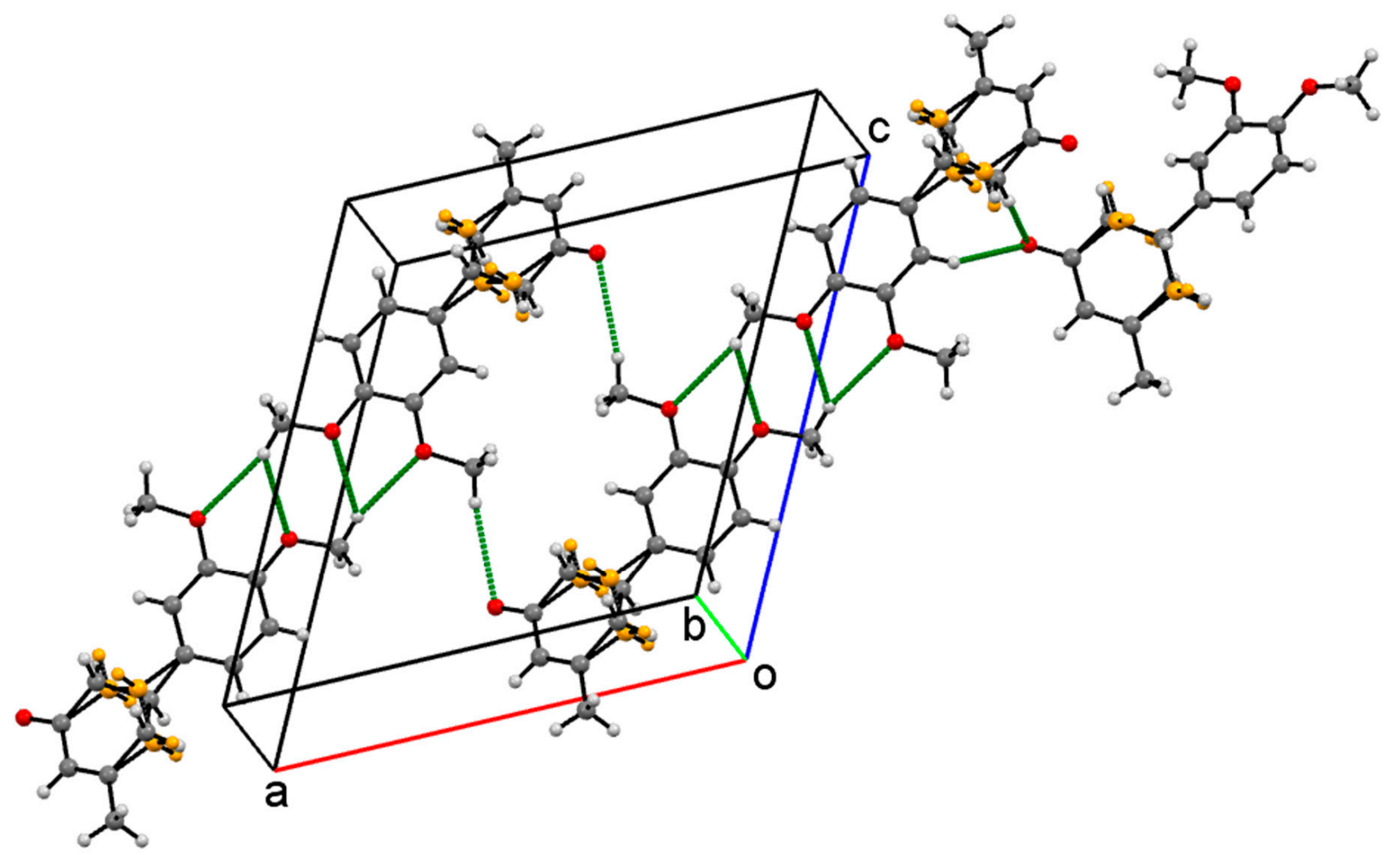

Figure 7. Packing of the crystals of compounds III and short contacts $\mathrm{C}-\mathrm{H} \cdots \mathrm{O}$ (dashed green line). 


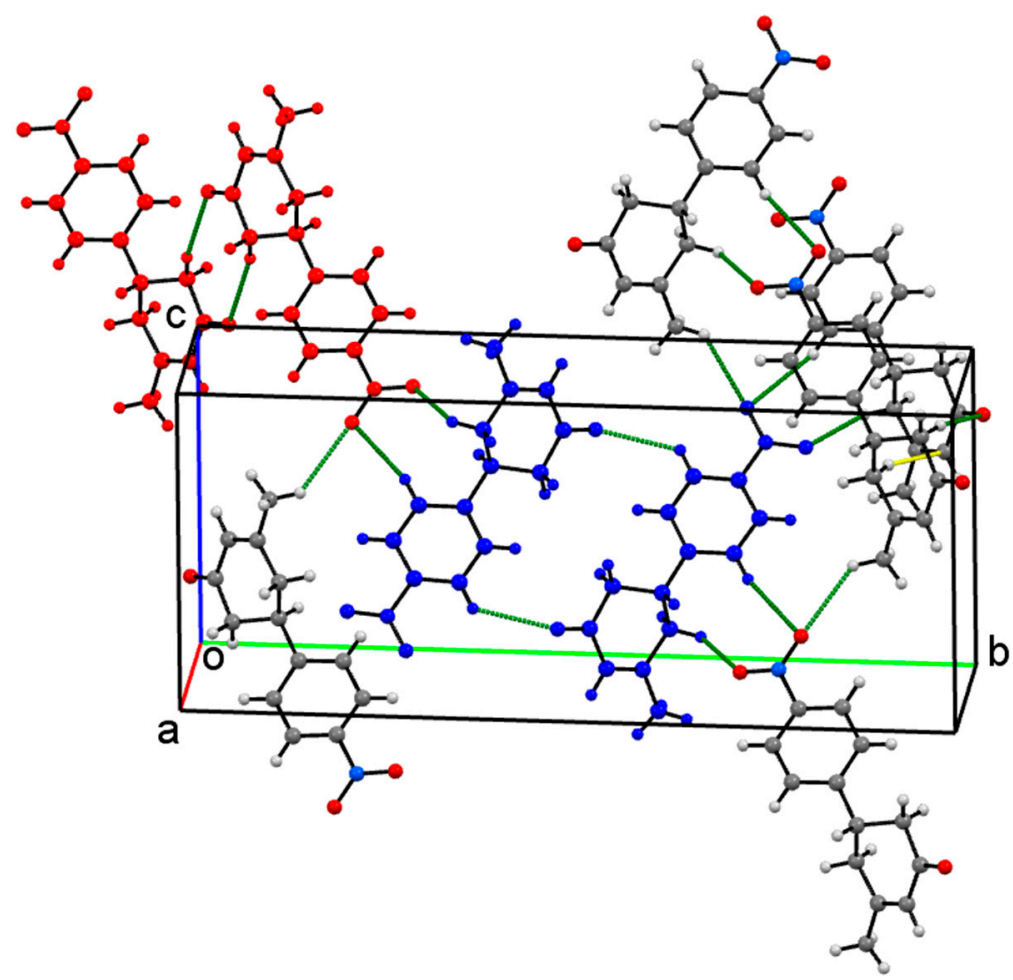

Figure 8. Packing of the crystals of compound IV short contacts $\mathrm{C}-\mathrm{H} \cdots \mathrm{O}$ (dashed green line) and $\mathrm{C}-\mathrm{H} \cdots \pi$ (dashed yellow line).

Compounds I and II were previously reported [28-30] from different synthetic routes, whereas compounds III and IV were reported using different reaction conditions [31]. A major disadvantage described for the Claisen-Schmidt reaction is the dominance of polymerization by-products $[32,33]$ with a remarkably high variation in yield from $10 \%$ to ca. $100 \%$ [33].

\section{Conclusions}

A basic Claisen-Schmidt condensation of aromatic aldehydes with acetone yield the expected products of mono-condensation (E)-but-3-en-2-ones. Concomitantly, the unexpected 3-methylcyclohex-2-enones were obtained by a cascade Robinson annulation reaction. The single-crystal structure determinations of compounds I and IV showed the expected structural and crystallographic features; the analysis of anisotropic displacement ellipsoids and the difference electron density map confirmed that such molecules are not disordered. Thus, the crystals of compounds I and IV belong to a typical case of a racemic compound, whereas in compounds II and III, unexpected and unique features were found. These compounds crystallize as co-crystals (solid solutions) of statistical disorder of trans s-cis/trans s-trans conformers (compound II) and the rarest case of enantiomeric disorder of a racemic mixture, pseudoracemate (compound III). Our work shows how the Claisen-Schmidt condensation step continues in cascade toward annulation, thus giving room for discussion and deeper understanding of this apparently straightforward reaction. In addition, an interesting question arises from the low yields often reported in the literature for the Claisen-Schmidt reaction potentially overlooking important and unexpected cyclic products.

Supplementary Materials: The following are available online at https: / www.mdpi.com/article / 10.3390/cryst11040404/s1, Figure S1-S12. CCDC-2075964, CCDC-2075965, CCDC-2075966, CCDC2075970 contain the supplementary crystallographic data for compounds I-IV, respectively. These data can be obtained free of charge via www.ccdc.cam.ac.uk/cgi-bin/catreq.cgi, by e-mailing 
data_request@ccdc.cam.ac.uk, or by contacting The Cambridge Crystallographic Data Centre, 12 Union Road, Cambridge CB2 1EZ, UK, fax; +44(0)1223-336033.

Author Contributions: Conceptualization, R.G.E.; methodology, M.A.O.-M., I.I.A.-O., W.M.-M. and Y.A.-R.; investigation, R.G.E.; NMR data acquisition, M.I.C. and J.C.; X-ray analysis, R.A.T.; writingoriginal draft preparation, R.G.E., M.A.O.-M., I.I.A.-O. and R.A.T.; writing-review and editing, R.G.E., M.A.O.-M., I.I.A.-O. and R.A.T.; project administration, R.G.E.; funding acquisition, R.G.E. and J.C. All authors have read and agreed to the published version of the manuscript.

Funding: Financial support from projects DGAPA (PAPIIT, IT200720), UNAM, and CONACYT (FOINS-307152) awarded to RGE.

Data Availability Statement: All data for this article are available from the corresponding author via email to enriquezhabib@gmail.com.

Acknowledgments: Support (SNI, 43468) from CONACYT awarded to IIAO is acknowledged. Technical assistance is acknowledged from Rocío Patiño and María de la Paz Orta for IR spectra; and Luis Velasco and Javier Pérez Flores for MS spectrometry. Support from CONACYT scholarships awarded to Marco A. Obregón-Mendoza (603692), William Meza-Morales (576707), and Yair AlvarezRicardo (576706) is acknowledged.

Conflicts of Interest: The authors declare no conflict of interest.

\section{References}

1. Mapoung, S.; Mapoung, S.; Suzuki, S.; Fuji, S.; Naiki-Ito, A.; Kato, H.; Yodkeeree, S.; Yodkeeree, S.; Sakorn, N.; Sakorn, N.; et al. Dehydrozingerone, a Curcumin Analog, as a Potential Anti-Prostate Cancer Inhibitor in Vitro and in Vivo. Molecules 2020, $25,2737$. [CrossRef] [PubMed]

2. Kondamudi, P.K.; Kovelamudi, H.; Nayak, P.G.; Rao, M.C.; Shenoy, R.R. Curcumin Half Analog Modulates Interleukin-6 and Tumor Necrosis Factor-Alpha in Inflammatory Bowel Disease. Pharmacogn. Mag. 2015, 11, S296-S302.

3. Yogosawa, S.; Yamada, Y.; Yasuda, S.; Sun, Q.; Takizawa, K.; Sakai, T. Dehydrozingerone, a Structural Analogue of Curcumin, Induces Cell-Cycle Arrest at the G2/M Phase and Accumulates Intracellular ROS in HT-29 Human Colon Cancer Cells. J. Nat. Prod. 2012, 75, 2088-2093. [CrossRef] [PubMed]

4. Suwito, H.; Jumina; Mustofa; Kristanti, A.N.; Puspaningsih, N.N.T. Chalcones: Synthesis, Structure Diversity and Pharmacological Aspects. J. Chem. Pharm. Res. 2014, 6, 1076-1088.

5. Mousavi, M.R.; Maghsoodlou, M.T.; Gharari, H. Sodium Carbonate-Catalyzed Claisen-Schmidt Condensation: One-Pot Synthesis of Highly Functionalized Cyclohexenones under Environmental Conditions. Res. Chem. Intermed. 2016, 42, 2233-2246. [CrossRef]

6. Rahman, A.F.M.M.; Ali, R.; Jahng, Y.; Kadi, A.A.A. Facile Solvent Free Claisen-Schmidt Reaction: Synthesis of $\alpha, \alpha^{\prime}$-bis(Substituted-Benzylidene)cycloalkanones and $\alpha$, $\alpha^{\prime}$-bis-(Substituted-Alkylidene)cycloalkanones. Molecules 2012, 17, 571-583. [CrossRef]

7. Sreevidya, T.V.; Narayana, B.; Yathirajan, H.S. Synthesis and Characterization of Some Chalcones and Their Cyclohexenone Derivatives. Cent. Eur. J. Chem. 2010, 8, 174-181. [CrossRef]

8. Gallier, F.; Martel, A.; Dujardin, G. Enantioselective Access to Robinson Annulation Products and Michael Adducts as Precursors. Angew. Chemie Int. Ed. 2017, 56, 12424-12458. [CrossRef]

9. Ghorai, M.K.; Samanta, S.; Das, S. Synthesis of 3,5-Disubstituted Cyclohex-2-en-1-one via a Five-Step Domino Reaction Catalyzed by Secondary Amines: Formation of (e)- $\alpha, \beta$-Unsaturated Methyl Ketones. Asian J. Org. Chem. 2013, 2, 1026-1030. [CrossRef]

10. Xiang, Z.; Liang, Y.; Chen, X.; Wu, Q.; Lin, X. D-Aminoacylase-Initiated Cascade Aldol Condensation/Robinson Annulation for Synthesis of Substituted Cyclohex-2-enones from Simple Aldehydes and Acetone. Amino Acids 2014, 46, 1929-1937. [CrossRef]

11. Jasinski, J.P.; Golen, J.A.; Samshuddin, S.; Narayana, B.; Yathirajan, H.S. Ethyl 2-amino-4,6-bis-(4-fluorophenyl)cyclohexa-1,3diene-1-carboxylate. Acta Crystallogr. Sect. E Struct. Reports Online 2012, 68, o585. [CrossRef] [PubMed]

12. Rai, S.; Patel, P.N.; Chadha, A. Preparation, Characterisation, and Crystal Structure Analysis of (2E, $2^{\prime}$ E)-3,3'-(1,4-phenylene)bis $(1-$ (2-aminophenyl)prop-2-en-1-one. Crystallogr. Reports 2016, 61, 1086-1089. [CrossRef]

13. Singh, V.D.; Salian, V.V.; Narayana, B.; Sarojini, B.K.; Kamni; Anthal, S.; Kant, R. Synthesis and Crystal Structure of a Chalcone Derivative. Crystallogr. Reports 2017, 62, 1157-1159. [CrossRef]

14. Wang, F.; Liu, Y.; Qi, Z.; Dai, W.; Li, X. Rhodium-Catalyzed Tandem Aldol Condensation-Robinson Annulation Between Aldehydes and Acetone: Synthesis of 3-methylcyclohexenones. Tetrahedron Lett. 2014, 55, 6399-6402. [CrossRef]

15. MNova Software. Available online: https://mestrelab.com/download/mnova/ (accessed on 10 April 2021).

16. Sheldrick, G.M. A Short History of SHELX. Acta Crystallogr. Sect. A Found. Crystallogr. 2008, 64, 112-122. [CrossRef]

17. Macrae, C.F.; Bruno, I.J.; Chisholm, J.A.; Edgington, P.R.; McCabe, P.; Pidcock, E.; Rodriguez-Monge, L.; Taylor, R.; Van De Streek, J.; Wood, P.A. Mercury CSD 2.0-New features for the visualization and investigation of crystal structures. J. Appl. Crystallogr. 2008, 41, 466-470. [CrossRef] 
18. Collins, A.; Barr, G.; Dong, W.; Gilmore, C.J.; Middlemiss, D.S.; Parkin, A.; Wilson, C.C. The Application of Cluster Analysis to Identify Conformational Preferences in Enones and Enimines from Crystal Structural Data. Acta Crystallogr. Sect. B Struct. Sci. 2007, 63, 469-476. [CrossRef]

19. Wang, Y.H.; Zou, J.W.; Zhang, B.; Lu, Y.X.; Jin, H.X.; Yu, Q. Sen Enone-Dienol Tautomerism of But-2-enal and Substituent Effect: A Theoretical Study. J. Mol. Struct. THEOCHEM 2005, 755, 31-37. [CrossRef]

20. Zhang, H.; Li, S.; Shi, X. (E)-2-Methoxy-4-(3-oxobut-1-enyl)phenyl Acetate. Acta Crystallogr. Sect. E Struct. Rep. Online 2008, 64, o1507. [CrossRef] [PubMed]

21. Patai, S.; Rappopor, Z. The Chemistry of Enones Part 1; Wiley: Hoboken, NJ, USA, 1989; pp. 1-1261.

22. Lin, F.F.S.; Servis, K.L. Nuclear Magnetic Resonance Spectroscopy. Rotational Isomerism in $\alpha, \beta$-Unsaturated Acyl Fluorides. J. Am. Chem. Soc. 1972, 94, 5794-5801. [CrossRef]

23. Loncharich, R.J.; Schwartz, T.R.; Houk, K.N. Theoretical studies of conformations of acrolein, acrylic acid, methyl acrylate, and their Lewis acid complexes. J. Am. Chem. Soc. 1987, 109, 14-23. [CrossRef]

24. Cremer, D.; Pople, J.A. A General Definition of Ring Puckering Coordinates. J. Am. Chem. Soc. 1975, 97, 1354-1358. [CrossRef]

25. Chion, B.; Lajzerowicz, J.; Bordeaux, D.; Collet, A.; Jacques, J. Structural aspects of solid solutions of enantiomers. The 3hydroxymethyl- and 3-carboxy-2,2,5,5-tetramethylpyrrolidinyl 1-oxyl systems as examples. J. Phys. Chem. 1978, 82, $2682-2688$. [CrossRef]

26. Rekis, T.; Bērziňš, A. On the structural aspects of solid solutions of enantiomers: An intriguing case study of enantiomer recognition in the solid state. CrystEngComm 2018, 20, 6909-6918. [CrossRef]

27. Brandel, C.; Petit, S.; Coquerel, Y.C. Structural Aspects of Solid Solutions of Enantiomers. Curr. Pharm. Des. 2016, 22, 4929-4941. [CrossRef] [PubMed]

28. Paul, S.; Gupta, M. A simple and efficient method for selective single aldol condensation between arylaldehydes and acetone. Synth. Commun. 2005, 35, 213-222. [CrossRef]

29. Bounora, P.T.; Rosauer, K.G.; Dai, L. Control of the Aqueus Aldol Addition Under Claisen-Schmidt Condition. Tetrahedron Lett. 1995, 36, 4009-4012. [CrossRef]

30. Bethi, V.; Fernandes, R.A. Traceless OH-Directed Wacker Oxidation-Elimination, an Alternative to Wittig Olefination/Aldol Condensation: One-Pot Synthesis of $\alpha, \beta$-Unsaturated and Nonconjugated Ketones from Homoallyl Alcohols. J. Org. Chem. 2016, 81, 8577-8584. [CrossRef]

31. Walker, G.N. Triton B in Synthesis of 3-Phenylcyclohexenones. J. Am. Chem. Soc. 1955, 77, 3664-3667. [CrossRef]

32. Surya Prakash Rao, H.; Jothilingam, S. Solvent-free microwave-mediated Michael addition reactions. J. Chem. Sci. 2005, 117, 323-328.

33. Zhuang, C.; Zhang, W.; Sheng, C.; Zhang, W.; Xing, C.; Miao, Z. Chalcone: A Privileged Structure in Medicinal Chemistry. Chem. Rev. 2017, 117, 7762-7810. [CrossRef] [PubMed] 